Conservation and Society 7(2): 130-140, 2009

$\underline{\text { Article }}$

\title{
Social-Natural Landscape Reorganised: Swedish Forest-edge Farmers and Wolf Recovery
}

\author{
Annelie Sjölander-Lindqvist \\ Centre for Public Sector Research, University of Gothenburg, Box 720, 40530 Göteborg, Sweden \\ E-mail: annelie.sjolander-lindqvist@cefos.gu.se
}

\begin{abstract}
The politics and the underlying reasons behind the recovery of the Scandinavian wolf population are increasingly contested. According to official policy, wolves should be guaranteed a place in the Swedish natural world. However, the conflict over whether Sweden should host a wolf population sets views on biodiversity and sustainable development against the perspective that local traditions and livelihoods are threatened by the return of wolves. These diverging environmental visions can be seen as competing interests and understandings of nature and wildlife. The desire of the state and nature conservation organisations to implement measures to provide conditions fostering wolf survival are counterbalanced by local action groups and community residents struggling to maintain conditions for conserving summer pastures, opportunities for hunting with sporting dogs, and other recreational activities such as mushroom- and berry-picking. Not only are these activities considered to have high natural and cultural value, the European Union (EU) has stated that small-scale farming is important for maintaining the landscape and safeguarding the survival of values associated with 'agri-environmental' habitats. The conflict between the interest groups is essentially about the access to and use of environmental resources. Squeezed between policies safeguarding wolf populations, preventing cruelty to animals and implementing activities required by the EU agricultural programme, farmers in areas with resident wolf populations have come to take part in processes that may reinforce rural identity.
\end{abstract}

Keywords: wolves, heritage, social-natural landscape, place, forest-edge farming, rural, hunters, conservation

DOI: $10.4103 / 0972-4923.58644$

\section{INTRODUCTION}

To protect biological environments, regimes for managing natural resources have been established worldwide. According to anthropologist Anna Lowenhaupt Tsing (2001), the concepts on which the enhancement of the biophysical environment rest can be characterised as part of a package of environmental protection strategies and practices (Tsing 2001:4). In one sense, the well-established discourse on sustainable development can be understood as an arena through which the agency and authority of particular actors are established by means of political directives and agreements (Shipton 1994). These range from supra-national negotiations concerning sustainability and biodiversity (e.g., the Rio Declaration, Berne Convention and Habitat Directive) to the local level, where the results of discussions and political agreements on environment are to be implemented (e.g., Local Agenda 21). These exercises may give rise to unintended consequences at the local level, resulting in conflicting perspectives on how best to manage heritage resources. These controversies engender a debate on the definition of 'nature', and on what are regarded as necessary measures for halting biodiversity loss and securing the well-being of endangered species (Sjölander-Lindqvist 2008; Sjölander-Lindqvist \& Cinque 2008; cf. Tsing 2001).

According to Tsing, and as has been demonstrated elsewhere (Sjölander-Lindqvist 2008), conservation and protection strategies may have material and social impacts on the lives and livelihoods of people (Tsing 2001; Brechin et al. 2003). The political decision to ensure a viable Scandinavian wolf population has proven that local discontent and frustration can occur when rural residents are restricted in their ability to carry on local traditions. The questions that arise locally concern the rights of people's access to private and public land. In the case of the Swedish wolf controversy, farmers and hunters in particular have found that their relationships with their local environments have been disturbed by the recovery of the wolf population. Consequently, the controversy has affected the social environment as well.

Copyright: (C) Annelie Sjölander-Lindqvist 2009. This is an open access article distributed under the terms of the Creative Commons Attribution License, which permits unrestricted use and distribution of the article, provided the original work is cited. 
While nature conservation organisations ${ }^{1}$ support government preservation actions to restore threatened ecosystems and the concept that wolves have a right to exist, their opponents ${ }^{2}$ respond that the landscape and local traditions of rural Sweden are being jeopardised by the reappearance of wolves in the countryside (cf. Skogen \& Krange 2003; Wilson 1997). Although pro-wolf groups promote fauna diversity, other interest groups maintain that other 'heritage' values - not just those of the predator biodiversity - must be increasingly recognised in the discourse on environmental conservation (cf. Ratamäki 2008; Skogen et al. 2008). Thus, while the research community, authorities and conservationists related to biological predators perceive that the wolf population is threatened due to poor pedigree (as it was founded by only three individuals, the genetic base is believed to be too narrow) and illegal killings (corresponding to about 15 percent of the annual mortality rate between 1999 and 2006) (Liberg et al.2005, 2008; Sand et al. 2004), ${ }^{3}$ other parties demand that the policy be changed. Many farmers and hunters living in wolf-inhabited areas state that the present population increase must be halted and that the wolves must be distributed more evenly throughout the country. They say that some regions are currently overpopulated by wolves, leading to attacks on private property (e.g., livestock and hunting dogs) and declining game population.

In this conflict over the presence of large predatory animals ${ }^{4}$ in the countryside and near human settlements and the activity, biodiversity and sustainable development perspectives, clash with the perspectives that local traditions and livelihoods are threatened by the presence of wolves in humans' immediate, nearby or more remote surroundings. Local networks and mobilisation campaigns have taken place among individuals who perceive themselves and their way of life to be threatened by the presence of wolves in their local environments. As has been demonstrated elsewhere, environmental conservation efforts reflect intentions that highlight the underlying assumptions and values of how the world ought to be (Ratamäki 2008; Skogen et al. 2008). Pertaining to this defence of the 'locals' are questions about access to and control of the environments of local communities (cf. McCarthy 2002).

The conflict is not about wolves per se. What the controversy illustrates is how divergent perceptions of the local environment contribute to, sometimes, an incompatible understanding of natural resources. Most importantly, the landscape provides a context for relationships between all those who use its resources, whether for economic, political, social, or cultural purposes. The state-initiated recovery of the Scandinavian wolf population will be used as an example of how differing understandings of 'nature' and 'landscape' compete, and eventually, how invocations of the local farming tradition and cultural heritage constitute a response to the environmental discourse on the protection and survival of an endangered species.

\section{THE NATURE-SOCIETY 'BORDERLAND'}

The forested areas of central and rural Sweden where the vast majority of some 200 wolves are residing and spreading could be considered a 'borderland' (cf. Massey 2005). In both the abstract and pragmatic sense, this land is where the diverging worldviews and interests of various stakeholders and actors meet. At the same time as 'landscape' and 'place' embody the presence of the experience, knowledge and memories of its actors and 'dwellers' (Ingold 1993), are also bound to the 'outside' world (Cosgrove \& Daniels 1988; Massey 1994, 2005), which imbues landscape and place with political implications (Löfgren 1997; Olwig \& Hastrup 1997).

Researchers of these issues agree that landscape and place constitute more than just a 'text' for the observer to 'read' (as defined by Relph 1976). More than mere showcases for shared experiences drawing on the shaping of collective meaning, landscape and place are demarcated by various societal frameworks (e.g., economic, political and legal) (Luhmann 1995). These frameworks leave place — where humans relate to the non-human world of wild animals and plants through various culture-dependent conceptualisations (Descola 1996, 2000)_potentially subject to struggle and controversy (Feld \& Basso 1996; Löfgren 1989; cf. Tilley 2006).

Wolf-management recovery measures and practices challenge local communities, since they reinforce the understanding that the rural landscape is not isolated and static, but rather always evolving. This is well-demonstrated by the implementation of Sweden's wolf management programme and by how agricultural and forested landscapes serve as meeting grounds between the physical world of living plants and animals (nature) and the outer, human world of local communities, authorities and science (Sjölander-Lindqvist 2008).

State efforts to support the recovery of wolf populations have been undertaken through the Swedish Environmental Protection Agency (SEPA); a body with the overall responsibility for the implementation of conservation measures and activities. These efforts have been undertaken through scientific activities and have regionalised wildlife management practices. Regional authorities, in close cooperation with natural scientists, ${ }^{5}$ carry out various delegated tasks: Taking inventory of large predatory animals and managing information activities, making decisions on compensation claims for damage inflicted by protected predators on private property such as livestock and dogs, making decisions on damage prevention, and introducing and monitoring measures to prevent illegal hunting. These activities, carried out in the field by researchers, administrators, hunters, ${ }^{6}$ and members of nature conservation organisations, are here defined as the 'borderland' of state-administrated efforts to safeguard predator populations. In the context of these activities and policies, wolves are no longer wild and remote; through control of its population, the wolf has become a part of the social landscape (Sjölander-Lindqvist 2008).

Many agree that place, as the locus where experiences and actions meet, thoughts and expressions are created, and knowledge is produced (Casey 1996), is relational, always evolving, and subject to negotiation with regard to meaning and social identity (Ingold 1993, 2000; Lee 2007; Massey 2005; Tilley 2006). As has been demonstrated, when local residents perceive themselves and their community as threatened, a local discourse on the meaning of place, landscape, historical 
community roots, and residents' values, concerns and interests, may be intensified (Hornborg 1994; Mairal Buil 2004; Sjölander-Lindqvist 2004, 2006, 2008). As Tilley says, "A symbolic return to the past often acts as a retreat from the uncertainties of the present" (Tilley 2006:14). When confronted with the vicissitudes of political decision-making, people within the places affected may respond by attempting to arrest time and limit change. According to Spiegel and Boonzaier, "if marginalised people did not feel threatened by cultural imperialism, cultural constructions of social identity would have little currency" (Boonzaier \& Spiegel 2008).

\section{RESEARCH APPROACH AND STUDY AREAS}

Although Swedish authorities today endeavour to promote the survival and recovery of the wolf through an integrated predator policy covering large predators (i.e., the brown bear, lynx, wolverine, golden eagle and grey wolf), in the past, laws and opinions identifying wolves as detrimental to humans and human activities led to the persecution of the species. For example, in 1647 , bounties were used to encourage wolf hunts, and remained in force for more than 200 years. Wolf battues for parish members (except for women, vicars and clerks) were obligatory, and regulated by provincial laws from the fifteenth century onwards.

When the wolf became a protected species in the mid 1960s, the population was estimated at between approximately 10 and 35 individuals, compared with an estimated 1,500 individuals in the early nineteenth century. Since the 1980 s, the wolf ${ }^{7}$ population has grown, and today numbers some 200 individuals. The 2008/2009 inventory identified 22 litters in the summer of 2008 (Viltskadecenter 2009) ${ }^{8}$ marking the first time ever that the politically decided interim target of 20 litters annually had been reached (Prop. 2000/01:57) (Figure 1).

The Swedish wolf controversy has been studied since 2004. Ethnographic methods have been chosen as the main strategies for empirically investigating how local residents in wolfpopulated areas relate to their surroundings, how they perceive the protection of large predators, and how they deal with the restraints imposed by the wolf policy. I chose to focus research on farmers and hunters, as these are the groups that, in official documents, have been pointed out as particularly vulnerable to the effects of the presence of large carnivores (SOU 1999:146; Prop. 2000/01:57). These groups are also the main actors expressing scepticism towards the wolf policy and its management.

In 2008, county administrative boards disbursed SEK 4.4 million $^{9}$ to farmers for preventive measures. Predatory attacks on livestock were compensated with a total of SEK 1.14 million..$^{10}$ Of the 504 attacks that took place, 69 percent were caused by wolves, totaling 317 killed, injured or missing livestock. Forty-one hunting dogs were killed or injured by wolves in the year of 2008. The dog owners were compensated with a total of SEK $271,000 .{ }^{11}$

Data were collected primarily by conducting in-depth interviews. Informal observations were also made at various public meetings. Newspaper and journal articles and websites have yielded additional insight into the 'wolf issue'-its

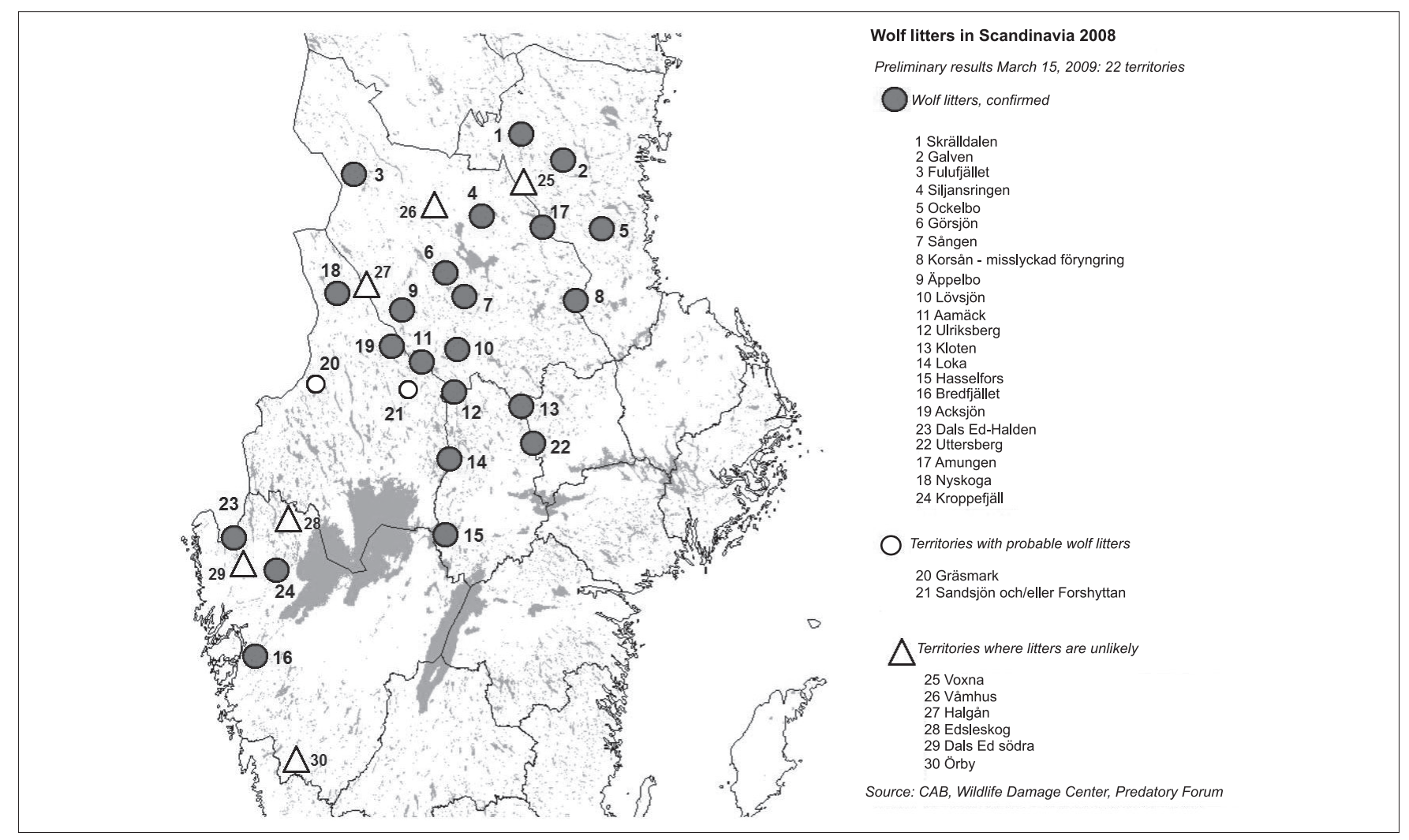

Figure 1: Map of wolf territories 
structures, actors and the main points of the debate. In interviews, individuals with both pro- and anti-wolf attitudes were asked about their views on wolves, their everyday activities, local practices affecting nature and natural resources, and experiences with the authorities' policy implementation. Through conversations, groups of farmers and hunters in particular expressed their opinions and values, providing a glimpse into their social world. Also interviewed were people who practiced neither farming nor hunting (Figure 2).

The interview results on which this article is largely based were conducted in Dalarna County in 2005. Dalarna, a vast region that covers 30,300 square kilometres ${ }^{12}$ in the middle of Sweden, has had wolf settlements for a long period of time. Fieldwork was conducted there in different areas. Particular efforts were made to include farmers who practiced seasonal foraging, a typical agricultural tradition in the region. This tradition, which involves leading livestock to summer pastures far from their home farms, has proved difficult to uphold due to the presence of large carnivores. This seasonal foraging typically entails unfenced forest grazing as well as grazing in open fields (both fenced and unfenced) close to summer farmhouses where animals can be kept.

Twenty-three interviews were carried out. In addition to interviewing people living in wolf territories (at the time of the study there were seven in Dalarna county) I also conducted ten interviews in an area where no wolves were residing at that time. Still, these informants lived adjacent to the wolf-habited areas. I chose this area to determine if attitudes in non-wolf territories were different from those in wolf-inhabited areas. I found that there were very minor differences of opinion regarding the wolf. What differed was that in non-wolf areas, people had fewer direct experiences with wolves. For example, there had been no wolf attacks on their livestock.

Fieldwork results from previous case studies complement

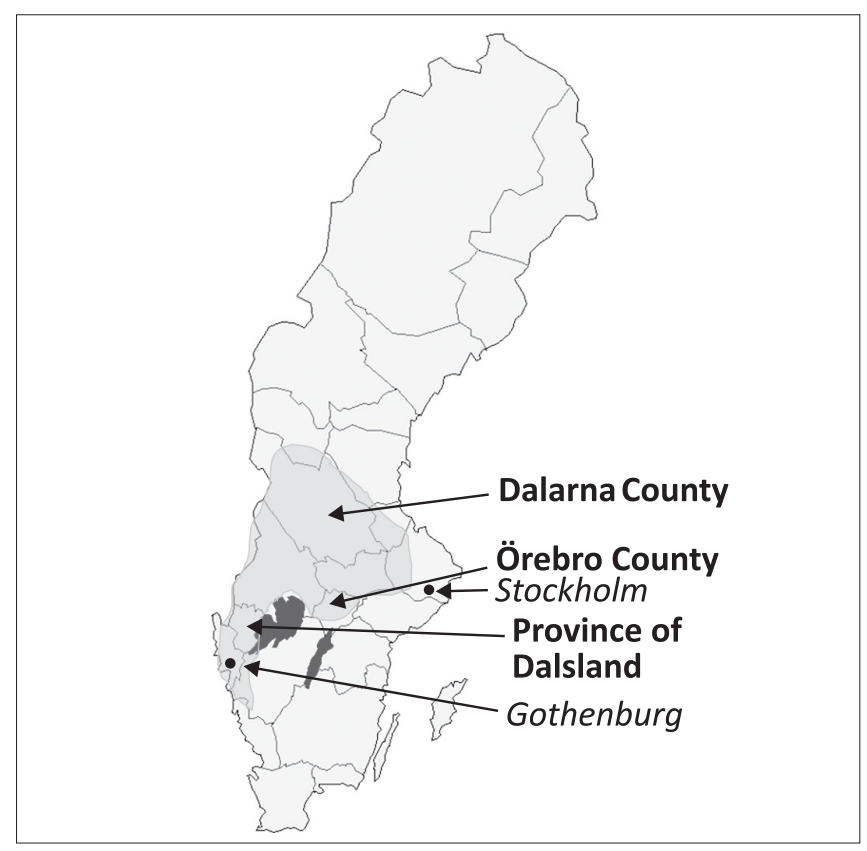

Figure 2: Wolf propagation in Sweden ${ }^{17}$ the results presented here. These studies were conducted in two wolf territories: Dals-Ed/Halden and Hasselfors, located some 250 to 350 kilometres north and northeast of Gothenburg, separated by Lake Vänern. ${ }^{13}$ The Dals-Ed/Halden territory is situated in the Dalsland province in Västra Götaland County. Forestry is the dominant industry in Västra Götaland, followed closely by pulp and steel industries. In this area, wolves were observed and traced for the first time in the winter of 1997-1998. Wolf pups have been born more or less regularly in the area.

The Hasselfors wolf territory that was studied is located east of Dalsland in the province of Närke in Örebro County. Industries, particularly engineering, mining and steel, are the major employers, with a much smaller number of individuals earning their income from agriculture. In 1994-1995 a single wolf was observed in the area, and later that spring it was confirmed that a female had migrated there. In spring 2000, wolf pups were born, although the pack came to suffer heavily from scabies. The female was put down in 2002. Soon thereafter, a new female established herself in the area; pups were born again in 2003 .

In total, 52 interviews were conducted in the summer and autumn of 2004 and 2005. Using convenience sampling, the interviewees included farmers, hunters, local entrepreneurs and other residents holding both pro- and anti-wolf attitudes. Throughout the interviews, I gathered opinions and values relating to the presence of predators in the area. Most interviews lasted from two to four hours (although one interview lasted for eight hours), and consisted of a set of general questions as well as follow-up questions on issues raised by the respondent. A written list of questions and topics served as a guide throughout the interview. For example, "What comes to your mind when you hear the word 'wolf'?"; "Has the presence of wolves changed your daily routine?"; "There is much talk about the wolf being unnaturally restored in Sweden-what do you think about that?"; "Do you think that the authorities have put enough effort into creating local consent with the implementation of predator politics?" Detailed notes were taken and later transcribed. The interviews were not recorded, since the wolf is a rather controversial issue, and some of the parties interviewed had even been threatened with violence due to their opinions on wolves. Interviewees holding both pro- and anti-wolf attitudes spoke about evening or late-night phone calls where they were told that they were 'being watched' and that 'they knew' where they lived, what cars they drove and even threatened that 'something could happen to their family'. In one area in particular, a pro-wolf interviewee feared being alone in the forests for safety reasons due to the hostile atmosphere in the community regarding wolf politics and management. In these areas, authorities conducting inventoryrelated activities in the field had had their car tires slashed. One of the interviewees spoke about how the tires of the informant and the guests' cars were cut just next to their residence. As a result, it was considered important to guarantee individual anonymity as much as possible. The ability of interviewees to trust the researcher is fundamental to ethnographic fieldwork, as it enables informants to relay information about their 
lives, experiences and feelings on certain matters more freely (Bernard 1994); the interview is to be regarded as more of a conversation than an interview per se.

The hostile atmosphere has also had administrative consequences. Although general hunting of wolves is not allowed, SEPA and administrative boards in counties with residential predator populations can issue controlled permits, valid for a limited period of time, for shooting an individual wolf that causes problems to farmers, hunters and other community residents. For example, in the summer of 2008, a male wolf attacked and killed about 80 sheep during a twomonth period in one wolf territory. The authorities issued a shooting permit and the wolf was killed during a specially organised hunt. Due to the local tensions that can arise under such circumstances, the organisation of the shooting party is conducted discreetly. Those volunteering for the hunt are asked not to discuss it; the name of the hunter who ultimately kills the wolf is not disclosed and even fellow hunters are often not informed.

Complementary fieldwork was carried on from 2004 to 2008. In addition to interviewing residents of wolf territories, public meetings arranged by local hunter associations and farmer organisations were observed. The fieldwork also included participant observations at the annual 'Wolf Symposium' held in northern Sweden. The symposium, which has been held since 1993, brings researchers, conservationists, stakeholder organisations and hunters together, with representatives from government, business, media and elsewhere to participate in discussions on national and international wildlife management issues. While the organisers of the event initially attempted to keep the discussion balanced, a number of both pro- and anti-wolf participants today believe that the symposium has recently taken on a pro-wolf and wolf conservationist focus.

\section{FOREST-EDGE FARMING AND HUNTING IN WOLF-POPULATED AREAS}

Although the number of agricultural production units is decreasing, there are still over 75,000 separate agricultural farm enterprise holdings in Sweden. Scarcely two percent of the Swedish working population is engaged in agricultural activity, compared to one quarter of the population half a century ago.

Nevertheless, large-scale farms are generally found in southern Sweden (where the land is comparatively more fertile and the growing seasons longer); the farming economy in wolf-populated areas is considerably smaller and more diversified. In all counties with resident wolf populations, the number of small farms is larger than the national average. ${ }^{14}$ In these areas, agricultural holdings are small-scale and farm incomes depend on several activities. Dairy or meat production, for example, is supplemented by income from leasing hunting grounds and by EU agricultural subsidies. Every third agricultural enterprise, for example, receives income from non-agricultural activities.

The rural regions are considered politically vital for biophysical, economic and social reasons, as evidenced by the system of EU agricultural subsidies and programmes such as the Common Agricultural Policy (CAP). The CAP gives farmers multiple, central roles: The CAP states that, aside from producing essential goods, environmentally sound agriculture contributes to the diversity and survival of the countryside. Farmers, consequently, play an important role in maintaining rural areas. The implementation of various national and international environmental policies highlights the fact that the cultural landscape of the forested areas of the country has implications beyond the narrow bounds of local natural resource extraction and conservation.

As agricultural land in Dalarna County was not partitioned in the nineteenth century (as had happened in most other parts of Sweden), farmers there have continued the tradition of leading their livestock to unfenced summer pastures, with cattle grazing in both forests and fields next to summer farmhouses. In these areas, farming is done at the edge of the forest or, in the case of seasonal foragers, in the forests themselves. Moving livestock to summer pastures is a tradition rooted in history, dating back at least several hundred years. In fact, archaeological findings from Norway indicate that summer pastures date back some 2,000 years, to the time of the Roman Iron Age. Seasonal foraging was widespread in the Nordic countries, being found throughout Norway, in most of Sweden, extending to the Finnish Lapland and Karelia, and introduced into Iceland at the time of colonisation in the eighth century. Even though the practice is declining, as the land in Dalarna County has not been partitioned, farmers there continue the practice as they have limited opportunities for cattle grazing near their home farms.

Farmers who employ agricultural seasonal foraging consider themselves part of a local heritage, and by taking their cattle to summer pastures they feel they are carrying on the traditions of the past. However, although shepherd boys or girls formerly accompanied the herds (usually consisting of cows, goats, sheep and horses), as fewer people depend on agriculture today, the farmers' abilities to actively herd their livestock has decreased.

From the farmers' point of view, the implementation of the Coherent Predator Policy (CPP), enacted by the Swedish government in 2001, to secure viable carnivore populations, may eventually lead to the demise of forest and farm communities, and consequently the loss of natural and cultural heritage. As regards the summer pasture farmers, they say that the presence of large carnivores makes it difficult to uphold their traditions due to their livestock being exposed to the risk of predatory attacks.

Although participatory measures were implemented following the CPP, many share the opinion that current politics around the issue increase the marginalisation of rural people and contribute to the depopulation trend occurring in rural areas. Interviewees perceive the presence of wolves as affecting rural livelihoods and the customary ways of life (cf. Lindquist 2000; Sjölander-Lindqvist 2008). Anti-wolf farmers in particular maintain that the effects of the presence of wolves- 
wolf attacks on livestock and hunting dogs — will increase the marginalisation of rural people and the depopulation of their areas (cf. Skogen \& Krange 2003).

'Many farmers have no education; they don't know how to speak to the authorities. Therefore, these farmers have limited abilities to voice their concerns.'

Summer pasture farmer

'It's not just about money; it's about the possibility of carrying out farming in this region. If we experience that we can't [carry out farming], great parts of the arable land will become overgrown.'

Summer pasture farmer

Another farmer states: “The decision-makers don't consider realities other than that of those who ride the subway in Stockholm".

According to the informants, the resulting abandonment of farming activity will consequently have effects beyond merely depopulating the countryside. The presence of wolves will not only restrict opportunities for recreational activities such as hunting, fishing, horseback riding, orienteering and berry- and mushroom-picking; it will also endanger biological and cultural diversity as livestock breeders and farmers will give up their livelihoods when the threats posed by wolves appear to be too heavy to bear.

'We bring almost all the sheep and the cows there. The whole family moves there as well, for the whole summer. One feels so good there. A summer pasture with its houses has a different soul. It's the keeping of animals there that constitutes the soul. The pasture has been used since the seventeenth century. Now we're the only ones there who keep animals. There was much more activity at the pasture in the 1950s. At that time, 90 animals were kept there during the summer to graze the fields and in the forest. If there aren't any livestock at the summer pasture it will die! It will turn into a totally different environment. It will become like a deserted house.'

Summer pasture farmer

The informants feel trapped: While the CAP subsidy framework requires them to contribute to the maintenance of rural areas, the predator policy restricts their ability to fulfill this requirement.

'It's a conflict for us farmers to hold the fields open at summer pastures. By keeping the landscape open we contribute to the biological diversity; that's why we're subsidised. We receive it to keep up this traditional way of farming the land. But, at the time of Sweden's entrance into EU there were no problems with large predators in the area. We're in conflict with the authorities who say that the EU subsidy covers the negative effects of the predator's presence in the landscape. But the subsidy is not meant for that.'

Summer pasture farmer
'We're supposed to keep the landscape open. We are told to bring more grazing animals, while at the same time there ought to be more predators. We are also told that "you cannot protect your animals" [for legislative reasons]. These aspects stand in conflict with one another. All the decisions taken have very little to do with our capabilities for combining traditional farming with predator presence.'

Summer pasture farmer

Besides maintaining traditional customs, the informants have expressed that they are contributing to the ongoing maintenance of an open landscape through the practice of seasonal foraging, which has evolved in line with the constraints and opportunities of the rural landscape. In addition, the farmers will be unable to fulfill the conditions the EU sets for granting economic support. Moreover, the environmental benefits of summer pasturing will be lost. As in Norway (Skogen \& Krange 2003), Swedish farmers too feel they have been subjected to injustices, and that their experience and activities are not being properly acknowledged. They assert that their small-scale farming methods have helped shape an open landscape, encouraged the diversification of flora and fauna, and maintained a particular cultural heritage, all of which they see threatened by the wolves residing in the forest. One farmer says:

'I need to bring a big bundle of hay every day to feed my cows. The whole idea with the environmental benefits of summer pasture farming is totally lost as a result.'

As they understand it, the different sets of regulations are in competition with each other: One extends their livelihood economically while also giving them cultural support; the other limits where they and their livestock can go.

'Ninety-five ewes at the summer pasture. We left the lambs at the home farm this year. By experience, the lambs are the ones that the predators attack. The sheep stick together at the summer pasture. And the cows do the same; they don't want to be there if there are wolves near the pasture grounds. You can't have livestock at the summer pasture if you have to bring them to forage from the farm. That's not the purpose! And to receive the EU subsidy the livestock must be grazing. When the livestock doesn't want to leave the enclosures where we have them at night to protect them from predatory attacks, they will starve and they won't drink. ... It becomes more and more difficult to keep up this traditional way of farming.'

Summer pasture farmer

'I moved here some years ago. I would have tried to practise the tradition of summer pasture grazing even without the EU subsidy, but it is the subsidy that allows me to survive solely on dairy production. I can let my cows live a more natural life.'

Summer pasture farmer

The increased political emphasis on the social aspects of 
sustainability, beginning in the early 1970s, has resulted in increased attention on fostering the exchange of concerns and experiences (Pitkin 1967, Dahl 1979). As pointed out by the Swedish government committee, preceding the CPP, neither biological, hunting, nor economic concerns alone should be decisive for policy design (SOU 1999:146). Notably, the government excluded social issues from the committee's assignment. The investigator, however, chose to add these as: "We must consider how the presence of large carnivores may affect the daily lives of people who reside in areas of large carnivores" (SOU:146, p. 185). The committee's work, which ultimately produced the CPP, called for local participation, as improved public involvement was considered to have a neutralizing effect on conflicts.

\footnotetext{
'An important part of the effort to reduce conflicts is to provide the concerned stakeholders information about, insights into and influence over decisions regarding large predators. We suggest that the different stakeholders be given improved opportunities for this, centrally and regionally, to reach a mutually agreed basis of knowledge for a discussion regarding the management of large carnivores. This is of crucial importance in efforts to mitigate conflicts. (SOU 1999:146, p. 213).'
}

The passage of the government bill and the CPP resulted in the establishment of the national Council for Predator Issues (CPI) to deal with the overall policy issues. Moreover, at the regional level, Regional Predator Groups (RPGs) were organised in counties with the resident predator population. The Swedish EPA directed that aside from various stakeholder groups, other concerned actors, such as police, prosecutors and municipalities, should be part of the RPGs. However, even though measures were implemented to improve participation, people felt distant and removed from the decision-making processes. As one farmer expresses:

'It [the presence of wolves] influences our lives. Those who live in wooded areas - why shouldn't you pay attention to them as well? It's important to have people living in rural areas. We must keep that in mind.'

Although the state offers financial compensation (though not always full compensation) for damage-prevention measures such as constructing predator-proof fences or buying herdguarding dogs, farmers feel they have very few options. At the time of this study, legislation restricted farmers from defending their property from predator attacks. Although legislative changes to increase farmers' rights to defend their livestock were under discussion, farmers employing the summer pasturing method still felt particularly vulnerable. As they have stated, the custom of summer pasture grazing is being threatened by the legal prohibition of lethal defence, and fencing in their cattle is not congruent with their farming traditions. The combination of economic factors and a limited ability to defend one's livestock or hunting dogs have contributed to the stakeholders' feelings of being caught in a dilemma: Instead of contributing to the ongoing maintenance of an open landscape and a rich fauna associated with unfenced cattle grazing, farmers must leave their cattle on summer pastures near their chalets in order to protect them from predatory animals in the landscape.

'Frankly, who is going to keep the landscape open? We must keep the tradition of grazing the land so it can continue to be a cultural landscape. We can't do that by running around with a motor saw!'

Summer pasture farmer

'It seems like dairy production is no longer valued after Sweden has become a member of the EU. Somehow it feels like the keeping of livestock is not important anymore. We're put against the decision that there are to be predators in the landscape.'

Summer pasture farmer

Another farmer speaks directly about the heritage aspects when meeting wolf conservationists:

'It [the presence of predators] changes peoples'life patterns far too much. It's a situation upon which I have no influence. I must speak for the importance of a cultural environment. We have different starting positions; I try to see the whole picture.'

Similar to the wolf-sceptical farmers, hunters have found that the presence of wolves in the forests threatens both smalland big-game hunting, as their hunting dogs have been put at risk. When using dogs (which track by scent and sight) to hunt elk, roe deer and small game such as hares, the dogs must be released, making them particularly vulnerable to wolf attacks. One hunter refers to the uncertainty of "not knowing whether the dog will return". Another says: "As soon as I have released my $\operatorname{dog}$ I feel worried. The more wolves there are in the forests, the greater risk that I won't get my dog back." Or: "You don't want your dog to be killed. It's a family member."

Hunters living in wolf-inhabited areas fear increased attacks on livestock, hunting dogs and eventually also on people as wolf populations grow (currently estimated at 200 in Sweden) and prey competition increases. As with the farmers, wolf-sceptical hunters say that the effect of the wolves' presence in the landscape will increasingly marginalise rural people and depopulate their areas. Similarly, hunters expressed concern that their decreased ability to hunt without exposing their dogs to wolves will leave the Swedish forests empty of hunters. ${ }^{16}$

\section{NATURE-CULTURE BOUNDARIES}

Although wolf-sceptical farmers and hunters argue that the maintenance of rural landscape and local traditions are threatened by the presence of wolves in the Swedish countryside (Sjölander-Lindqvist 2008; Sjölander-Lindqvist 
\& Cinque 2008; cf. Skogen \&Krange 2003; cf. Wilson 1997), pro-wolf groups maintain that wolves have a right to exist there and that action must be taken to restore a threatened ecosystem. Such arguments are also evident in how the authorities have handled the government's predator policy (Cinque 2008). Administrators and the pro-wolf groups share a belief that the anti-wolf groups' opinions with regard to the causes and effects of the wolves' presence in the landscape are inconsistent, and that these opinions must be addressed. The authorities regard scientific knowledge as central to both decision-making and alleviating worries about the effects of a large carnivore presence (Sjölander-Lindqvist \& Cinque 2008). The authorities also assume that more people will agree with the predator policy when scientific information is disseminated to the concerned stakeholders and interest groups (SOU 1999:146). Regional and national authorities aim to achieve local consensus and compliance on the matter of wolves' living conditions and their future among Swedish fauna via cooperative efforts involving central authorities, non-governmental organisations (NGOs) and stakeholder groups. Through consultative forums (e.g., Regional Predator Groups), ${ }^{16}$ the decision-makers strive to inform the concerned stakeholder groups, believing this will eventually result in a consensus.

The social-natural landscape is effectively reorganised to support the recovery of the wolf. The national and regional authorities' mandate to implement measures to ensure its survival and proliferation in Sweden represents a national environmental project with consequences for local residents. The viewpoints and perspectives of the concerned stakeholders, authorities and nature conservation societies and organisations on the effects of the presence of large carnivores in the countryside have diverged (SjölanderLindqvist 2008; Sjölander-Lindqvist \& Cinque 2008). We see how the various actors and stakeholders struggle over access to and use of natural resources. For generations, some groups have based their exploitation of forests and agricultural lands on the premise of a localised domain. By contrast, the modern environmental discourse on the fragility and scarcity of biodiversity contributes to broadening the scope of natural resource extraction, as the land used for traditional hunting, silviculture and farming also constitute the areas of interest for enhancing viable carnivore populations.

Informant uncertainty regarding the continuance of farming and hunting reflect the fact that the landscape has a significant meaning for local residents. Cantrill \& Senecah (2001) suggest that "our conception of the natural environment is framed by our experiences bound to local settings" (Cantrill \& Senecah 2001:186). Through agricultural and hunting practices that include performance, representation and action, people socialise the landscape (Appadurai 1995). Through hunting, for example, which is practised by nearly 280,000 Swedes, social relationships and networks are established and strengthened (Barnard 2004). Farming and hunting are also considered activities that depend on the use of local natural resources. As such, the forested landscape is essentially a cultural landscape that is home to networks of relationships between people, as evidenced by local traditions and livelihoods. As they are culturally and socially encoded, the land people use contributes to how they relate to the natural and social world of forests, which are inhabited by game, summer grazing livestock and large carnivores.

Farming and hunting traditions in forests and forest fringe areas involve a constant interaction with nature. Through farmers' and hunters' engagement, action and the practice of bringing livestock and dogs into the forest, the 'wild' becomes domesticated. By upholding their traditions, anchored in time and space, the boundaries between wild and domesticated become blurred. The remote domains of nature extend into peoples' homes and domestic spheres. Following intrinsically from this, the wilderness species enter into the cultural properties of 'home' and 'home ownership' (SjölanderLindqvist 2008).

The wilderness has traditionally been viewed as a space beyond human control (Descola \& Pálsson 1996). This concept, however, has been re-negotiated in the context of the wolf controversy. We see this in the scientific activity, which was intended to meet the demand for knowledge on the wolf, which began with the increase in the wolf population in the 1980s and 1990s. The biological research community and SEPA have explored (via the Wildlife Damage Centre founded in 1996) the development and spreading of the wolf population across Sweden. Data on wolf genetics and social behaviour, along with the wolves' effects on large herbivore populations, have been gathered through activities that demand the active presence of humans in the wilderness and the monitoring of wild animals. By employing various data collection techniques (e.g., snow tracking, radio telemetry, GPS tracking and collecting and examining droppings), the environmental space of the 'wilderness' is no longer beyond society's control.

By implementing policies to restore the Scandinavian wolf population, human interaction with nature has broadened. Forested landscapes now host more groups than just those who, through traditional farming and hunting, are carrying out forest-based activities. In addition, the authorities' field staff carries out inventory-related activities, meaning that the wolfinhabited lands also become opportunities for large-carnivore tourism and are visited by people drawn to the recreational aspects of carnivore-populated areas. This increasing politicisation and commoditisation (cf. Appadurai 1986, Kopytoff 1986) of nature highlights how cultural landscapes, as living examples of cultural heritage, encompass both tangible and associative values. When wolves occupy a local habitat, additional cultural and natural values are added to the residents' local environment, as the area becomes of interest in terms of carnivore conservation. In the wolf-inhabited landscape, biological and cultural diversities intertwine. Similarly, in the landscape of forest-edge farming, agricultural labour interacts with 'protection labour' (Knight 2000).

Local residents, however, perceive these ecosystem recovery initiatives as threatening their cherished cultural heritage. By invoking 'heritage', local residents contribute 
to the politicisation of the landscape. Farmers, in particular, may be responding to the challenge when they (willingly or unwillingly) adjust their farming practices in response to the presence of wolves in the countryside.

Localising the protection of the Swedish natural resources from further degradation and species extinction has consequences for local communities - beyond the pragmatic assertion by farmers and hunters that their cultural practices should be considered central to the issue. By insisting that farming traditions in forest-edge areas have helped maintain the appearance of the landscape and the characteristics of its flora and fauna, farmers intrinsically link themselves and their actions to the biophysical environment. In doing so, cultural practices are celebrated, their uniqueness is emphasised (cf. Kopytoff 1986; Olwig 2005), and the past is actively linked to the present. Forest-edge farming can, therefore, be seen as an act of sustaining cultural practices. By returning to the particular agricultural traditions of a specific landscape, local residents can retreat from the uncertainties of the present (cf. Tilley 2006), which are imposed by state regulation and enforcement.

The various policies imposed on the administration of the socio-natural landscape contribute to the exposure of the boundaries of that landscape. Through state-administered initiatives, either to protect predator populations or to uphold agricultural traditions and rural heritage, the boundaries of forest-edge agriculture and hunting are no longer 'closed' nor stable.

\section{CONCLUSION}

Aside from the goal of enhancing biodiversity, implementing a coherent policy for large predators in Sweden contributes to the re-negotiation of the meaning of landscape. Farmers and hunters find themselves in 'a configurative complex of things' (Casey 1996:25). By actively celebrating particular cultural practices, regarded as significant for both economic and identity reasons, community members recall the past and try to protect their communities from further change and external intrusion that imposes re-negotiation. As such, the farmers' activities and practices related to the place and landscape in wolf-inhabited areas are highly politicised. Subjected to various administrative and legal frameworks, resulting from global discourses on sustainable development and biodiversity preservation, farmers find themselves trapped between competing regulations, facing uncertainties from the presence of predators (which are perceived to be imposed on the local community by national policy decisions) and feeling that their contributions to the rural cultural environment are being overlooked.

The presence of wolves in the countryside in central Sweden-where most of the Swedish wolf population is found - has caused considerable disquiet among the concerned stakeholders. Squeezed between policies promoting the preservation of wolf populations and the activities required by the EU agricultural programme, farmers residing in areas with resident wolf populations tend to be reluctant to welcome the wolves' presence. Farmers and hunters worry that the wolves threaten their rural landscape and heritage; this has contributed to their scepticism regarding wolves, as have state regulations and conservationist intervention in their local environments.

The implementation of policies safeguarding the Scandinavian wolf is giving rise to a policy quandary, in that farmers are expected to use production methods compatible with environment protection. Dependence on the European Union's economic grants (CAP Reform 1992)—which are received only if environmentally friendly production methods are employed - and the authorities' expectations that farmers must adjust to the risks that the carnivore presence poses to rural communities have caused disquiet and frustration among the informants, who complained about not being allowed to protect their livestock from wolf attacks. For the local community, broader policies and concerns impinge on people's everyday lives in many subtle ways, and social relationships, the understanding and use of the local environment, thoughts about the future, and memories of the past are all affected. Wolf protection measures and activities have served to intensify prior notions and values regarding the forested landscape.

By investigating how the forest and forest fringes in wolfpopulated areas serve as a 'borderland'-mediating concepts of the place of wild and domesticated animals in the remote and nearby landscape - we have built an understanding of how farmers in particular, and hunters as well, conceive their world, their actions and their practices related to the landscape. By demonstrating how farmers link themselves intrinsically to the landscape, we see how people actively situate it and socially and culturally construct it. Through discourse on heritage, cultural practices are celebrated, dynamically linking the past to the present. As such, heritage claims become occasions for resistance, in which 'heritage' is deployed as a means of establishing social identity and as a political marker of authenticity.

\section{NEXT STEPS?}

So far, authorities have not grasped the complexity of the wolf issue. Cinque's (2008) investigation of administrative discretion indicates that there is a lack of guiding principles for regional administrators in the wolf management field. Put simply, they have too many options (Cinque 2008). A clearer and more explicit policy framework could contribute to improved policy implementation. As regional authorities are subordinate to the national SEPA, the issue of more regulated administrative discretion lies at the political level. This means that politicians have to advise the national authority on adjusting the policy framework and communication between SEPA and the responsible ministries may need to improve.

In addition, participatory possibilities and measures must be acknowledged to have value. As we have seen, farmers and hunters believe that their opinions of and experiences with the wolf policy have been marginalised and not given proper attention in the decision-making process. Although the CPP states that the authorities are to pay increased attention to stakeholder perspectives, research has demonstrated that the authorities responsible for implementation of the practices 
have distanced themselves from the circumstances that have given rise to the conflict. Thus, although we have seen the establishment of new and decentralised programmes for the management of large carnivores - reflecting the proposition that local empowerment and participation are essential to fulfil politically determined environmental objectives (Prop. 2000/01:57) - the involvement of non-authorities in the decision-making is limited. A 'deadlock' has perpetuated the existing conflict at the RPG forums, where administrators state that the participants' arguments must be built on scientific knowledge. They effectively construe the different opinions of participants as illegitimate (Sjölander-Lindqvist and Cinque 2008).

The final point to make is on competence. Cinque demonstrates in her work (2008) that the administrators find themselves lacking in the knowledge and skills required to meet people and discuss issues with them. As wildlife biologists, they are trained to address issues concerning wild animals, which mean that many of them may have insufficient knowledge with regard to the social and cultural aspects of the presence of wildlife.

\section{Acknowledgements}

The research on which this article is based was supported by the Swedish Environmental Protection Agency. My appreciation goes to my colleagues Serena Cinque and Anna Bohlin for their useful comments on my research findings. I would especially like to thank the anonymous reviewers for their invaluable comments on the first version of the manuscript.

\section{Notes}

1. Such as Svenska Rovdjursföreningen (Swedish Carnivore Association), Svenska Naturskyddsföreningen (Swedish Society for Nature Conservation) and the World Wildlife Fund (WWF).

2. Such as Folkaktionen Ny Rovdjurspolitik (Peoples' Campaign for A New Predator Policy, author's translation), Svenska Jakt \& Fritidsgruppen (the Swedish Hunting and Outdoor Recreation Club, author's translation) Sveriges Glesbygds Trygghet (For the Safety of Sweden's Marginal Areas, author's translation. Also referred to by pro-wolf proponents as 'Shoot, Dig and Shut Up').

3. Estimates of wild food sources indicate that Sweden could have about 745 individual wolf habitats. Such a scenario, which would correspond to 5,000 stationary wolves, indicates very limited opportunities for moose and roe deer hunting. Researchers suggest that if there would be no hunting, 2,000 wolves ( 300 wolf territories) are needed to regulate elk and roe deer populations. This is, however, considered politically and practically impossible (Sand et al. 2004). To sustain a healthy population, at least 500 wolves are needed.

4. Besides the grey wolf, these include the brown bear, golden eagle, lynx, and wolverine, all of which are protected by law.

5. In January 2000, The Scandinavian Wolf Project (SKANDULV), an umbrella organisation for Scandinavian research projects on the wolf, was established to coordinate biological research initiatives. SKANDULV and the Wildlife Damage Centre (founded in 1996) carry out extensive fieldwork in both Sweden and Norway (since several wolf territories cross the Swedish-Norwegian border) to build knowledge of the wolf population. Some of the research projects concern the development and spread of wolf populations, wolf genetics, wolf social behaviour, the effects of wolves on large, herbivore populations, and the establishment of wolf territory. Primary data on wolves are collected by monitoring the Scandinavian wolf population, primarily by snow tracking (conducted since the late 1970s), excrement analysis and DNA analysis. Data gathered using motion-tracking devices can be used for more than just wolf and wildlife research. Where wolves have been provided with tracking collars, a 'wolf telephone' has been established; location data are transferred to an answering machine that individuals can call for updates on the whereabouts of wolves in the area.

6. The Swedish Association for Hunting and Wildlife Management has long played a vital role in the predator debate in Sweden. By organising its 195,000 members (of a total of 300,000 hunters in Sweden), the association has been active in the predatory debate and has fulfilled an important function in hunting and wildlife management.

7. Including packs, scent-marking pairs, and other resident individuals; besides these categories of resident wolves, there are also migratory wolves whose numbers may be difficult to estimate.

8. Although most of the Scandinavian wolf population is found in Sweden, some packs reside in both Norway and Sweden.

9. Approximately $€ 412,000$ ( $€ 1=$ SEK 10.68).

10. $€ 107,000$.

11. $€ 25,400$.

12. Equal to the size of Belgium.

13. Swedish provinces (landskap) were dispossessed of political and administrative authority in the seventeenth century. Political and administrative tasks for regional management were handed to county administrative boards and county councils.

14. Lake Vänern is the largest lake in Sweden (nearly 6,000 sq. km).

15. Source: Statistiska centralbyrån [Statistics Sweden](2007).

16. In 2000, the Wildlife Damage Centre found that the use of hunting dogs had decreased by between 31 and 52 percent in five investigated wolf territories as a result of the presence of wolves in the forests (Karlsson and Thoresson 2000).

17. Established in all counties with residential predator populations.

\section{REFERENCES}

Appadurai, A. 1995. The production of locality. In: Counterwork. (ed. Fardon, R.). Pp. 204-225. London and New York: Routledge.

Barnard, A. (ed.). 2004. Hunter-gatherers in history, archaeology and anthropology. Oxford: Berg.

Bernard, H.R. 1994. Research methods in anthropology: Qualitative and quantitative approaches. California: Sage Publications.

Boonzaier, E. and A.D. Spiegel. 2008. New wine in old bottles: Tradition and heritage in a multicultural modern world. In: New South African keywords (ed. Shepherd, N. and S. Robins). Cape Town: Jacana.

Brechin, S.R., P.R. Wilshusen, C.L. Fortwrangler and P.C. West (eds). 2003. Contested nature: Promoting international biodiversity with $j$ in the twenty-first century. Albany: State University of New York Press.

Cantrill, J.G. and S.L. Senecah. 2001. Using the "sense of self-in-place" construct in the context of environmental policy-making and landscape planning. Environmental Science \& Policy 4: 185-203.

Casey, E.S. 1996. How to get from space to place in a fairly short stretch of time: Phenomenological Prolegomena. In: Senses of Place. (eds. Feld, S. and K.H. Basso). New Mexico: School of American Research Press.

Cinque, S. 2008. I vargens spår. Myndigheters handlingsutrymme i förvaltningen av varg. Göteborg: Förvaltningshögskolan and CEFOS. Doctoral dissertation.

Cosgrove, D. and S. Daniels (eds). 1988. The Iconography of Landscape. Cambridge: Cambridge University Press.

Dahl, R. 1979. Procedural democracy. In: Philosophy, politics and society. (eds. Laslett, P. and J.S. Fishkin). Oxford: Blackwell Publishers.

Descola, P. and G. Pálsson (eds.). 1996. Nature and society: Anthropological perspectives. London: Routledge. 
Descola, P. 2000. In the society of nature. Cambridge: Cambridge University Press.

European Commission. 1992. Common agricultural policy. http://ec.europa. eu/agriculture/index_en.htm (last retrieved on April 5, 2009).

Feld, S. and K.H. Basso (eds). 1996. Senses of place. New Mexico: School of American Research Press.

Hornborg, A. 1994. Environmentalism, ethnicity and sacred places: Reflections on modernity, discourse and power. Canadian Review of Sociology and Anthropology 31: 245-267.

Ingold, T. 1993. The temporality of the landscape. World Archaeology 25: $152-174$

Ingold, T. 2000. The perception of the environment: Essays in livelihood, dwelling and skills. London and New York: Routledge.

Jordbruksverket and Statistiska centralbyrån (Statistics Sweden) 2007. Jordbrukstatistisk årsbok 2007. www.sjv.se/download/18. b1bed211329040f5080002908/JSA + Hela.pdf (last retrieved April 5, 2009).

Karlsson, J. and S. Thoresson. 2000. Jakthundar i vargrevir-En jämförelse av jakthundsanvändningen i fem olika vargrevir och statistiken över vargangrepp på hundar 1999/2000. Viltskadecenter. http: //www. viltskadecenter.com/publikationer/friktionsrapport.pdf.

Karlsson, J., H. Andrén and H. Sand. 2004. Vad bestämmer antalet vargar och deras utbredning i framtiden? In: Skogsvilt III. (eds. Jansson, G., C. Seiler and H. Andrén). Pp.54-57. Riddarhyttan: Grimsö forskningsstation, Sveriges Lantbruksuniversitet.

Knight, J. (ed.). 2000. Natural enemies: People-wildlife conflicts in anthropological perspective. London: Routledge.

Kopytoff, I. 1986. The cultural biography of things: Commodisation as process. In: The social life of things: Commodities in cultural perspective. (ed. Appadurai, A.). Pp. 64-91. Cambridge: Cambridge University Press.

Lee, J. 2007. Experiencing landscape: Orkney Hill land and farming. Journal of Rural Studies 23: 88-100.

Liberg, O., H. Sand, H.C. Pedersen and P. Wabakken. 2008. Dödlighet och illegal jakt $i$ den skandinaviska vargstammen. Pp. 42 . Viltskadecenter Rapport nr 1-2008.

Liberg, O., H. Andrén, H.C. Pedersen, H. Sand, D. Sejberg, P. Wabakken, M. Åkesson, et al. 2005. Severe inbreeding depression in a wild wolf Canis lupus population. Biology Letters, 17-20.

Lindquist, G. 2000. The Wolf, the Saami and the urban shaman: Predator symbolism in Sweden. In: Natural enemies: People-wildlife conflicts in anthropological perspective. (ed. Knight, J.). Pp. 170-88. London: Routledge.

Luhmann, N. 1995. Social systems. Stanford, CA: Stanford University Press.

Löfgren, O. 1989. Landscapes and mindscapes. Folk 31: 183-209.

Löfgren, O. 1997. Mellanrum: Vita fläckar och svarta hål i storstadens utkant In: Moderna landskap. (eds. Saltzman, K. and B. Svensson). Pp. 45-69. Stockholm: Natur och Kultur.

Mairal Buil, G. 2004. The invention of a minority: A case from the Aragonese. In: Facility siting: Risk, power and identity in land use planning. (eds.
Boholm, A. and R. Löfstedt). Pp.144-159. London: Earthscan.

Massey, D. 1994. Space, place and gender. Cambridge: Polity Press.

Massey, D. 2005. For space. London: Sage.

McCarthy, J. 2002. First world political ecology: Lessons from the wise use movement. Environment and Planning A 34: 1281-1302.

Olwig, K. 2005. Representation and alienation in the political landscape. Cultural Geographies 12: 19-40.

Olwig, K. and K. Hastrup (eds.) 1997. Siting culture: The shifting anthropological object. London: Routledge.

Pitkin, H. 1967. The concept of representation. Berkely: University of California.

Prop. 2000/01: 57. Sammanhållen rovdjurspolitik. Miljödepartmentet.

Ratamäki, O. 2008. Finland's wolf policy and new governance. The Journal of Environment Development 17: 316-339.

Relph, E. 1976. Place and placelessness. London: Pion Limited.

Shipton, P. 1994. Land and culture in tropical Africa: Soils, symbols and the metaphysics of the mundane. Annual Review of Anthropology 23: 347-377.

Sjölander-Lindqvist, A. 2004. The effects of environmental uncertainty on farmers' sense of locality and futurity: A Swedish case study. Journal of Risk Research 7: 185-197.

Sjölander-Lindqvist, A. 2006. "Den är ju inte i fårhagen på studiebesök”-om lokala perspektiv och uppfattningar om varg och rovdjursförvaltning. Pp. 1-81. Gothenburg: CEFOS, University of Gothenburg, Report 2006.

Sjölander-Lindqvist, A. 2008. Local Identity, science and politics indivisible: The Swedish wolf controversy deconstructed. Journal of Enviromental Policy and Planning 10: 1: 71-94.

Sjölander-Lindqvist, A. and S. Cinque. 2008. Negotiating "dead-end" decisions: Organising regional groups in predatory animal issues in Sweden. In: Società Italiana di Scienza Politica-XXII Convegno Annuale, Pavia, Italien, 4-6 September 2008. Pavia: Italien.

Skogen, K. and O. Krange. 2003. A wolf at the gate: The anti-carnivore alliance and the symbolic construction of community. Sociologia Ruralis 43: 309-325.

Skogen, K., I. Mauz and O. Krange. 2008. Cry wolf! Narratives of wolf recovery in France and Norway. Rural Sociology 73: 105-133.

SOU 1999: 146. Rovdjursutredningen-Slutbetänkande om en sammanhållen rovdjurspolitik. Miljö-och samhällsbyggnadsdepartementet (Ministry of Environment and Social Structure).

Tilley, C. 2006. Introduction: Identity, place, landscape and heritage. Journal of Material Culture 11: 7-32.

Tsing, A.L. 2001. Nature in the making. In: New directions in anthropology and environment. (eds. Crumley, C.L., A.E. van Deventer and J.J. Fletcher). Pp. 3-23. Oakland: Altamira Press.

Wilson, M.A. 1997. The wolf in Yellowstone: Science, symbol, or politics? Deconstructing the conflict between environmentalism and wise use. Society \& Natural Resources 10: 453-469.

Viltskadecenter. 2009. Lägesrapport pr. 2009-03-01-Vargföryngringar 2008. http: //www.viltskadecenter.se/images/stories/Publikationer/ vargforyngringar_2008_prel.pdf (last retrieved on April 5, 2009). 